\title{
Imágenes de satélite simuladas a partir de las salidas del modelo de mesoescala HARMONIE-AROME
}

Ángeles Hernández Carrascal $^{1}$ (ahernandezc@aemet.es)

${ }^{1}$ AEMET / Departamento de Desarrollo y Aplicaciones / Área de Modelización

\section{RESUMEN}

El modelo de transferencia radiativa RTTOV (y otros) permite estimar las radiancias o temperaturas de brillo que un instrumento de satélite soportado mediría, desde una posición específica, en una banda espectral específica, para un perfil atmosférico y condiciones de superficie dados, por ejemplo obtenidos como salida de un modelo de predicción numérica del tiempo (PNT). Las radiancias o temperaturas de brillo así obtenidas para una banda espectral pueden presentarse como una imagen de satélite simulada, bien en los puntos de rejilla del modelo numérico, bien en las posiciones de los píxeles de las imágenes reales.

Las imágenes simuladas proporcionan una información muy valiosa sobre los campos del modelo de PNT en el que están basadas, y tienen una gran utilidad como herramienta en predicción operativa y también en el desarrollo de modelos númericos. En el Centro Europeo de Predicción a Plazo Medio (CEPPM), desde 2005 se producen y diseminan de forma rutinaria imágenes de satélite simuladas usando RTTOV y las salidas del IFS, su modelo global de PNT. En AEMET, en el SAF de nowcasting se producen imágenes simuladas para todos los canales de SEVIRI, también a partir de las salidas del IFS y usando RTTOV.

En el Área de Modelización se está desarrollando una aplicación para la producción de imágenes simuladas a partir de las salidas del modelo de área limitada HARMONIE-AROME, también usando el modelo de transferencia radiativa RTTOV, para su uso general en el grupo HIRLAM, del que AEMET es miembro. En este póster se presenta el estado actual de la aplicación y los planes para el futuro próximo.

PALABRAS CLAVE: imágenes simuladas; imágenes sintéticas; predicción numérica. 
